\title{
Amazon Development and the Political Economy of Water
}

\author{
Desenvolvimento da Amaônia e a economia política da água
}

Antonio A. R. Ioris

Lecturer in Geography

School of Geography and Planning, Cardiff University, UK

IorisA@cardiff.ac.uk

\begin{abstract}
One of the main processes of politico-economic change in the Amazon Region today is the construction of large-scale water projects, especially for hydroelectricity generation and river navigation (associated with export-oriented agribusiness and mining). The article discusses resource grabbing and environmental injustices through a cultural, political economy framework to assess the main direction and the internal dimensions of development trends. Water projects are assessed concerning the contradictory advance of modernity, the ramifications of corrupted practices and the narrow basis of a prevailing technocratic and reductionist rationality.
\end{abstract}

Keywords: Political Ecology; Water Management; Hydropower; Agribusiness; Navigation; Political Economy.

\section{Resumo}

Um dos principais processos contemporâneos de mudança político-econômica na Região Amazônica é a implementação de projetos hídricos em larga escala, especialmente para geração de hidreletricidade e a navegação fluvial (que são geralmente associados ao agronegócio e mineração orientados para a exportação). Este artigo discute a captura de recursos por relações econômicas e o aumento de injustiças ambientais através de uma abordagem de economia política cultural empregada para avaliar a direção e as dimensões internas das tendências do desenvolvimento conservador. Os projetos hídricos são avaliados em relação ao avanço contraditório da modernidade ocidental, às ramificações de práticas questionáveis e de uma racionalidade tecnocrática e reducionista predominante.

Palavras-chave: ecologia política, gestão da água, energia hidrelétrica, agronegócio, navegação, economia política

"À l'heure où les décisions des "experts" s'enorgueillissent d'être le résultat de statistiques anonymes et glacées, désobéir, c'est une déclaration d'humanité.” (GROS, 2017, p. 19)

\section{INTRODUCTION}

Let's start with a graphic example of heavy water engineering that, although distant from the Amazon, has a number of important and revealing parallels nonetheless. The scene is the Russian summer of August 1933. A group of 120 leading writers went on a boat tour along the recently inaugurated White Sea Canal, one of the evidence of the supposed success of the first FiveYear Plan of the Soviet regime. The canal was built at a neck-breaking speed between 1931 and 
1933 using the manual labour of 120,000 workers, most of them prisoners sentenced for minor political faults or, very often, for no reason whatsoever (apart from falling prey to intrigue and anonymous denunciations). Imprisonment was then justified as a humanitarian project to rehabilitate such 'bad people'; in practice, it included anyone who had any opinion about the corrupt and ultra-violent regime of comrade Stalin. The trip was highly beneficial to the purposes of a notoriously tyrannical government aiming to manipulate, control and exploit its people. As in the case of many other projects, such as the Moscow-Volga canal and Aral Sea irrigation, water infrastructure in the Soviet Union costed lives, destroyed reputations and drained scarce national resources. But the abundant signs of cruelty and state propaganda associated with the White Sea Canal did not affect the mood during the festive trip. On the contrary, as described by Figes (2008), guests were in high spirit, enjoying the best food and drinks, oblivious to national famine around most of the country.

What happened in the USSR in the last century anticipated or mirrored many other situations in which the control of water became closely associated with economic development goals, nationalist ideologies and the affirmation of modern values. The Five-Year plans (there were thirteen in total in the history of USSR) were clearly influenced by the modernist planning paradigm that followed the October Revolution and characterised by technocratic strategies loaded with scientificism, positivism and a strive for economic growth (SCOTT, 1998). Comparable examples include the Marathon Dam in Greece, Nehru's dams in India (deviating from Gandhi's opinion about postcolonial development), Roosevelt's dams, navigation and irrigation along the Tennessee Valley as part of New Deal strategies, interconnected hydropower schemes in the Scottish Highlands and dams in the Upper Douro in Portugal, the Aswan Dam in Egypt, among many others. The story is well known and repetitive. Yet, the construction of dams and other related infrastructure is time and again used to propel and celebrate country modernisation. But it also reveals the ontological impurity of modernity, always partial, fraught with gaps and contradictions. In that context, this article is intended to broaden the discussion on the shortcomings of development and socio-ecological impacts of dam construction in the Brazilian section of the Amazon (around $80 \%$ of the area covered by the Amazonian biome is located within Brazilian borders). This is still a largely understudied question, particularly regarding the revival of past extractive practices combined with the advance of national and international marked demands facilitated by neoliberalism strategies. More than 140 hydropower schemes are already working or under construction in the Amazon, with another 428 under consideration, which is going to result in cumulative and monumental impacts (LATRUBESSE et al., 2017).

The goal here is not to revisit economic statistics or the details of engineering projects, but to assess the main direction and the internal dimensions of development trends. Lived Amazonian 
spaces have been dramatically transformed by sustained migration, new production technologies, urban expansion and new relations of production. Growing towns, farms, industries and households all need electricity, which means that the construction of hydropower schemes are one of the top infrastructure priorities of national, regional and local policy-makers and politicians. Further than that: the main reasoning behind policies and discourses is that the Amazon has so much freshwater (actually, more than any other continent) that it should play an increasing role in energy supply to the country. It is well known the overall mismatch between benefits being accrued by construction companies and well-off socioeconomic groups outside the Amazon, whilst most of the negative consequences are borne by peasants and communities located where dams are built (IORIS, 2019).

Nonetheless, the unevenness of development and the perverse socio-ecological processes of change will be examined through the lens of Cultural Political Economy (CPE). Our analysis is aimed to contribute towards better understanding the dialectics between what is unique and local with the more widespread and global features of water management modernity. Consequently, it deals with what Bourdieu (2004) defines as the tension between history and reason. Before examining the interconnected dimensions of dam construction in the Amazon, it is necessary to briefly appraise the explanatory capacity of CPE and the occurrence of some excesses.

\section{CULTURAL POLITICAL ECONOMY}

The departure point of this article is the claim that CPE represents a privileged entry point into the problems of water allocation, use and conservation in the world today. Political economy, against a background of intense market globalisation, mounting interdependencies and striking socio-spatial inequalities, is inescapably cultural and those processes cannot be reduced to narrow economic thinking and simplistic formulas advanced by many right- or left-wing authors alike. On the contrary, the cultural basis of cross-scale interactions should be at the centre of any analysis of global or local politico-economic trends. Aiming to overcome reductionist formulations, CPE emerged in the 1990s in the context of the so-called 'cultural turn' of social sciences against historicist or transhistorical analyses of structuralist authors. It was an attempt to take more seriously the complex relations between meanings and practices, as much as values and traditions, that underpin a way of life and associated economic relations (JESSOP; OOSTERLYNCK, 2008). CPE has overlapping and synergies with similar approaches, including cultural studies, critical geography and social anthropology, which share the same interest in unfolding the complex political, economic and socio-cultural conditions at stake as a result of global integration and socioecological change. Best \& Paterson (2010) rightly point out that the cultural, political economy of contemporary Latin America, with its flows of migration, money and information, is just not 
amenable to simplistic models. Still, CPE has been rarely employed in the study of the politics of natural resource management and environmental change. However, it can help to connect the economic activity with discourses, symbolisms and political contestation.

The main strength of CPE authors has been their ability to make sense of development's hegemony without reducing everything to the economic sphere. It means recognising that there are gaps and interstices in human relationships, notably in the practices of daily life, family traditions and aspirations that flourish and proliferate beyond the economy. Work on CPE is concerned with the variety and non-linearity of the lived economic experiences, what Mann (2012) calls the 'sidewalk path' dimension that complements the 'main flow' going down the street. Closely associated with the cultural turn, CPE has helped to restore the weight of identities, discourses, work cultures and the social and cultural embedding of economic action (SAYER, 2001). A culturesensitive political economy should, therefore connect the economic and non-economic elements of world complexity. Two influential authors in this debate, Jessop and Sum (2006) combined Gramscian and Foucauldian ideas to explore the relationships between economic imaginaries and inter-subjective meanings, arguing that CPE occupies a middle ground between reified economics (the naturalisation of economic categories) and sociological approaches that address socio-cultural activities and micro-level interactions.

On the other hand, however, the work on CPE has also reflected the exaggerations common to post-structuralist approaches, in particular the tendency to privilege the immaterial and symbolic dimensions of reality. Most post-structuralist authors typically emphasise the primacy of flat ontologies and specific circumstances but at the expense of generalisations and commonalities that also need to be recognised. It makes sense to reject rigid, all-encompassing grand narratives, but the (dynamic) structures of local, national or global reality also need to be considered in the analysis of socio-ecological relationships and historical agency; as observed by Chang (2011, p. 120), because "a factor is structural... does not mean that the outcome of its influence is predetermined". Even if it is an important achievement of the CPE scholars the condemnation of narrow thinking behind the conventional political economy, it is ill-advised to disregard the strong influence of economic forces, market transactions and institutional settings. After all, there is not only different but also a necessity in the world (SAYER, 1992), bearing in mind also that necessity is "the becoming-necessary of the encounter of contingencies" (ALTHUSSER, 2006, p. 261). There is another, even more, serious distortion derived from the obsession of post-structuralists, including many scholars working on $\mathrm{CPE}$, with the inadequacies of grand theories. It is the risk to reinforcing mainstream economic approaches by the 'back door', that is, through an inadvertent association with neo-classical economic thinking. Culturalists and marginalists both attack the alleged narrowness of 
many political economy studies, which are found wanting and struggle to deal with world intricacies.

Cultural studies and marginalist economics have thus concurred in the attempt to challenge basic politico-economic categories, particularly those of the Marxist tradition rightly or wrongly associated with infrastructure and economic growth in the USSR mentioned above (i.e. the labour theory of value, class-based disputes, labour-power as a commodity, surplus value as exploitation, etc.). Because marginalists concentrate on the determination of prices through the consideration of the marginal utility of goods and services rather than the focus of classical political economists on value, order and economic growth, one can often find connections with culture-sensitive and location-focused explanations of economic processes. However, here lies a trap: despite its methodological emphasis on individual preferences and people's specific circumstances, marginalist economics is erected upon a clear positivistic paradigm that proclaims the superior rationality of market freedoms to impose business rationality on all dimensions of human experience (this is intensely present in contemporary policies adopted for the development of the Amazon region and dam construction). Standing in evident contrast with the gains obtained with the cultural turn, marginalism is equally or even more rigid, ideological and schematic that the politico-economic argument that it tried to subvert, especially because of the reduction of the complexity and nonlinearity of the world to the monodimensional, alienation and utilitarianism of market transactions (commonly mystified through the uncritical use of statistics and mathematical models). In other words, the prominence on subjectivism and individualism did not prevent marginalist thinking from decontextualising economics processes from their socio-cultural context.

Nevertheless, it is not enough to denounce the deceptive positivism of marginalist approaches. However, it is crucially important to retain CPE firmly within the politico-economic critique of disembedded markets and capitalist relations of production and reproduction. If CPE is a great beneficiary of the cultural turn, it is possible to argue that the emphasis on subjectivities, differences and uniqueness may have gone too far, at least when post-structuralist authors deny the importance of generalised trends or the lived impacts of structural and functional characteristics of social relations. Some common biases have been the exacerbated prominence of flat ontologies and non-hierarchical relations at the expense of conscientious and nuanced economic and sociological thinking. This must serve as alert to the overindulgences of the cultural turn and the danger of eroding political and the economic dimensions in favour of a messy and shallow 'cultural Bazar'. That is because the illuminating focus on the social and cultural embedding of economic activities cannot merely ignore the contribution of political economists to unlock the complexities of capitalist socioeconomy (SAYER, 2001). It means that the full potential of CPE can be realised 
through a permanent and creative association between theory and practice, critical philosophy and philosophising for change.

Consequently, there is no need to ditch the critical basis of political economy to be able to encompass socio-cultural issues and subjectivities. On the contrary, the explanation of the mounting problems of capitalism and search for economic alternatives must necessarily embrace the morethan-economic elements of reality (beyond the reductionist thinking of previous scholars and revolutionaries). It is significant that Gramsci's elaboration on the philosophy of praxis, described especially in Notebooks 10 and 11, was not only a provocative invitation for rupture and reconstruction, but his entire political project was largely influenced by a sustained cultural and historical sensitivity (GRAMSCI, 1971). Bond (2016) and others describe the question of revolution in the 21 st century as a transition to an eco-socialist society, where social, economic and ecological questions are considered together in the search for environmental justice. An ecosocialist transformation will require multiple forms of mobilisation, global alliances and ideological and practical prefiguration, what undeniably opens space for the contribution of CPE. One particular chapter of that controversy is the fate of the Amazon and its modernisation, subjection and exploitation in the name of water development. It is impossible to deal with the full picture of water development in the Amazon here, and the next pages will briefly consider policies and strategies related to dam construction in the region. The intention is to make use of CPE to offer a commentary on the controversial politico-economic context of water in the Amazon, which has been firmly based on the simplification of socio-natural systems according to the powerful discourse of resource exploitation, territorial occupation and economic growth.

\section{DEVELOPMENT AND DAM CONSTRUCTION IN THE AMAZON}

The above defence of CPE reinforces the need for a more sophisticated consideration of development and associated socio-ecological changes. That means placing equal importance on cultural, the political and the economic processes lived, negotiated and contested by different social groups. CPE should be also sensitive to spatial and temporal patterns that connect, in unpredictable ways, the local, regional, national and global spheres of politico-economic interaction. This would convert CPE into an even more heuristic approach that can be used to understand the complexity of development frontiers, as in the case of dam construction and socio-cultural tensions in the Amazon. It will become clear below that the disjuncture between the formal enunciation of water projects in the name of national development and the actual intricacies of their implementation has produced a highly unequal distribution of opportunities and gains, whilst new meanings and values have been embodied in concrete life-experiences related to country modernisation. The evolution of 
water management has been an integral element of the imposition of hegemonic ideologies and the mobilisation of labour and resources for economic growth. As argued by Reis \& Mollinga (2015), what is in place here is a crucial dialect of discursivity and materiality.

Many new large projects are being planned, and several have already been built in the Brazilian tracts of the Amazon. However, all have suffered from the lack of transparency, proper risk assessment and convincing cost-benefit analyses. The contradictory side of dam construction, even according to mainstream economic reasoning, has been denounced among others by Carvalho (2006); Fearnside (2016); Hanna et al. (2016); McCormick (2011) and Scholz (2005). Such questions are not dissimilar to those associated with Stalin's water schemes a few decades earlier and are, thus, a problem of cultural, political economy par excellence. The range of issues related to dams in the Amazon are not merely economic, political or cultural, but spiralled exactly at the interface between those three realms. Dams, as part of the infrastructure of development, are not only 'temples of the modern world' (paraphrasing Prime Minister Nehru), but are one of the most emblematic manifestations of certain politico-economic values at the expense of culture, ecology and resourcefulness by those affected by the advance of modernity. Dams work as one of the most powerful forces of the commodification and oversimplification of nature; as indicated by Marx (1976), when the products of labour are brought into relation with each other as equivalent values, concreteness and specificities are lost, and the material expressions of labour are converted into 'hieroglyphics'. A discussion of the generalities and commonalities of dam construction that underpins regional development in the Amazon reveals a great deal about the contradictions of economic trends and the tragedy of the joint exploitation of society and the rest of nature covered by the hieroglyphics of capitalist modernity.

\section{POLITICS OF DAM CONSTRUCTION IN THE AMAZON: POLITICO- INSTITUCIONAL PROCESSES IN PLAY}

Development, as it is normally advocated nowadays, is a relatively recent global project of economic growth, national building and market-based integration, which was launched in the context of post-World War II geopolitics and North American hegemony. Brazil and the few other Latin American countries that had some nascent industrial infrastructure already in place in the 1940s benefited from the opportunities provided by the war economy and continued to pursue import substitution policies. Those strategies were adopted in a context of fragile, formal democratic rule, increasing urban migration and persistent socio-political hierarchies. The Amazonian section of Brazil was still at that point, a vast economic frontier with a sparse population most involve in subsistence production and extractivism (IORIS, 2018). Gradually, the national government started to introduce development policies, including new banks, research 
centres and regulatory agencies, that were primarily associated with rubber production. An emblematic milestone was the famous speech delivered by President Vargas (the champion of Brazilian industrialisation) in Manus, in 1940, calling for the occupation and modernisation of the region (promising that it was time for the Amazon to become a new chapter in the "history of civilisation"). One important consequence was the Plan of the Economic Valorisation of the Amazon in 1953 and the creation of the Manaus Free Trade Zone (Zona Franca) in 1957, initially as a trade port and, after 1967, as an important industrial centre (aimed to lessen the concentration of industries in the southeast and south of Brazil).

The first phase of large-scale infrastructure construction in the Amazon can be described as the time of the 'blunt bulldozer', between the 1960s and 1980s, when Brazil was ruled by a military dictatorship that worked to preserve conservative interests through a plan of centralised and autocratic modernisation. National development policies benefited from cheap international credit, initially provided by bilateral and multilateral banks and, since the 1970 s, increasingly by private banks holding Eurodollars associated with the recycling of OPEC money after the dramatic oil price increases (O'BRIEN, 1991). Brazil became particularly addicted to low-interest loans, which served to produce temporary economic rents, build expensive (often questionable) engineering works and accumulate capital in the hands of the well-off groups (soon leading to serious inflation and the collapse of the state ability to repay or serve loan interests with the cessation of 'friendly' credit). The incorporation of the Amazon region into national development was essential as an exogenous and uncompromising process, formulated in Brasília, exalted by economic groups in the southeast of the country and encouraged by multilateral financial organisations. It involved the imposition of external socio-spatial order, a process that had already started in the 16th century by the Portuguese colonial government, only now with modern colours and magnified transformative power. Once again, foreign politico-economic influences and extraterritorial demands would blend with local cultures and contribute to forging economic, social and spatial hierarchies.

A main politico-economic vector associated with modernity and eagerly advanced by the military dictatorship in the Amazon was road construction; but not any road, it had to be schemes of Amazonian proportions such as the Transamazon and BR-163 motorways. New roads assisted the opening of farms, which was encouraged by fiscal benefits and by legislation that considered the removal of vegetation as 'improvement' of private property (IORIS, 2016). Bulldozers were not only used to build roads and clear land for pastures and crops, but also to divert rivers and erect dams for hydroelectricity generation. Various large-scale projects were planned without much regard for local socio-ecological and socio-cultural features. The objective was to occupy and rapidly grow the economy before other nations (USA and China in particular) could seize the Amazon. The scientific evidence is still patchy but consistently demonstrate the serious and often misunderstood ecological 
and hydrological impacts associated with dam construction in the region ever since, as well as the disruption of riparian communities, changes of local habits and interpersonal relations, and destruction of historic and archaeological sites.

The military regime ended in 1985 in a context of political discontent, economic instability and great uncertainty. The regime was increasingly undermined by macroeconomic turbulence created by spiralling public debts, high inflation and exhaustion of state funds, which had been the main economic driver of the so-called 'Brazilian economic miracle' (between 1968 and 1973) fuelled by international loans. The Eletrobrás Plan 2010 - published in 1987 by the Energy Ministry and a cause of great controversy due to early leaks - listed 297 sites suitable for the installation of new plants with more than $30 \mathrm{MW}$ in the country; 68 of those were located in Amazonia but had to wait until the economic turbulence was overcome. After a lengthy transition and benefit from the legitimacy earned since the presidential election of 1989 (the first after 29 years), the historical circumstances were ripe for pro-market reforms and the reorganisation of the state by the new governments. The economic stability and inflation control offered by the Real Plan, of 1994 provided the basis for legal and institutional adjustments. The Cardoso administration (1995-2002) promoted successful monetary and fiscal adjustments, which fuelled an ambitious reform of the state apparatus along the lines of liberalisation and growing integration into global markets. As in other comparable countries, a distinct neoliberal project was eagerly implemented (e.g. Spain and France) or maintained (e.g. UK and Portugal) by centre-right political groups coalesced around the previously leftist Cardoso.

The Real Plan was complemented by an institutional restructuring that included the removal of trade barriers (and at times the promotion of imports to avoid inflation), rigid monetary regulation, adjustments in the labour market and reorientation of the state apparatus. Energy policies and the electric sector were directly affected by the powerful neoliberalism agenda; for instance, the reduced tariffs charged by public utilities, a mechanism largely used during the 1980s to contain inflation, was removed in favour of private suppliers. Water and environmental regulation were also transformed due to the introduction of new legislation directly informed by the doctrine of ecological modernisation, such as the 1997 Water Law, centred on river basin committees, water licences and correspondent charges (IORIS, 2010). The reorientation of government agencies and the introduction of new water legislation paved the road for the expansion of private gains based on natural resource publicly or collectively owned (IORIS, 2009). New energy and water regulatory agencies, among others, were created to oversee the growing involvement of the business sector in infrastructure construction and operation. A private energy market was created in 1995 (reorganised in 2003) in which consumers and providers can freely trade energy with each other. 
The neoliberalism adjustments adopted in the 1990s - with all idiosyncrasies and contingencies of any neoliberalisation process (IORIS, 2013) - led to the third, still unfolding phase of dam engineering in the Brazilian Amazon. It has been a period of neo- developmental strategies and formalist environmental and socioeconomic regulation. Between 2003 and 2016, under presidents, Lula and Dilma, national policies and government initiatives were characterised by a peculiar combination of populist measures (such as conditional cash transfers, as in the case of the Family Stipend [Bolsa Familia] programme) with the reassured guarantees to financial and business sectors. During this third phase, the country benefited from the commodity boom. It increased the reliance on foreign goods, at the cost of de-industrialisation and over appreciation of the national currency. In that context, the state renewed the programme of infrastructure construction with increasingly larger dams in the Amazon through associations between public and private construction companies, closely supported by local and national politicians and the hegemonic economic sectors. National dam construction policies had to be adjusted because the best sites, situated closer to the main industrial and urban areas in the south and southeast of Brazil, were all taken in the process, which means that there is now a pressure to move to new areas, particularly in the Amazon. Despite mounting impacts and growing controversies, the hydroelectric exploitation of Amazonia has never been as much on the agenda as now, since the region contains around $50 \%$ of the national electric potential. The main areas for expansion are located in the Madeira, Xingu and Tapajós rivers, as analysed below.

\section{ECONOMICS OF DAM CONSTRUCTION IN THE AMAZON}

Making use of the schematic division of the recent economic history of the Amazon - the three moments of regional development described above - it is important to realise that since the 1960s the energy sector in Brazil became highly centralised and controlled by an elite group of engineers and economists within the federal government, in articulation with state administrations (CONCA, 2006). Most of the existing hydropower infrastructure in Brazil today was introduced by the military dictatorship, which then benefited from the availability of international development money (petrodollars in particular) and the repression of social and political opposition (IORIS, 2007). As a result of coordinated politico-ideological and economic strategies, around 74\% (it used to be more than $90 \%$ a few decades ago) of electricity consumed in Brazil comes from hydropower schemes (ANEEL, 2008), which make the country one of the leaders of renewable energy generation in the world (what from a CPE perspective can be considered a mixed blessed achievement). The Amazon was not ignored in the programme of dam construction. A region that makes up $54.4 \%$ of Brazilian territory and encloses $78 \%$ of the reserve of national freshwater was 
'judged' by the dictatorial government guilty by its geography and 'condemned' to go through a process of water development (a risky endeavour, taking into account the region's particularities, especially the extensive plains and complex socio-ecology). The Amazon, despite the incredible amount of surface water (around a fifth of the planet's freshwater), is quite ill-suited for dams and swaths of land and forest have been flooded in exchange for relatively little electricity.

Among the projects introduced by the military government were Coaracy Nunes, in Amapá, and Curuá-Una, in Pará, but the worst example of incompetence was Balbina. This plant furnishes Manaus with very low efficiency of the creation concerning the flooded area. Balbina dam, inaugurated in 1989 near Manaus, which flooded 2,360 $\mathrm{km}^{2}$ for a very low power-generation capacity of only $250 \mathrm{MW}$ and long periods of low operation due to low flows. Balbina is often described as the 'worst hydroelectric scheme in the world', as it releases more methane (a powerful greenhouse gas that is accumulated at the bottom of the reservoir) than very inefficient coal power plants; besides, Manaus is now connected to the national grid, which makes Balbina largely redundant. Samuel also had a questionable efficiency and the site of the dam is so flat that engineers have had to build 30 miles of dikes to help create a lake of $520 \mathrm{~km}^{2}$; the Samuel dam has $217 \mathrm{MW}$ of capacity, which was recognised even before the construction as insufficient to serve the growing cities of Porto Velho and Ji-Parana. The national electricity utility Eletrobrás conceded that Balbina and Samuel were mistakes and it was affirmed by one of its directors that "air surveys and topography measurements were not accurately made because of the tree cover" (SIMONS, 1989).

The largest scheme built during this first phase was Tucuruí (inaugurated in 1984), which generates electricity, especially for aluminium smelting. The project received very limited environmental consideration, as it was common for all projects advanced by the military government (although it has changed superficially after the introduction of more comprehensive environmental regulation in the 1990s, as the example of Belo Monte demonstrates). During the filling of the Tucuruí reservoir, a large quantity of timber was left and then died, also leading to a large release of methane. With the construction of the Tucurui dam, 2,430 $\mathrm{km}^{2}$ of forest were flooded, and more than 33,000 people (besides the indigenous population) had to be resettled. The scheme also inundated part of three indigenous areas (Parakanã, Pucuruí and Montanha), the effect of which was added to the impact of the transmission lines on their land; also, the artificial lake Tucuruí led to the extinction of various biological species and the proliferation of water-borne illnesses (COMISSÃO PRÓ-ÍNDIO DE SÃO PAULO, 1991). Many of these problems remained unsolved and were again present in the next phase of dam construction.

The second phase of dam engineering was focused on politico-economic adjustments, which coincided with the neoliberal reform of the Brazilian state in the 1990s. The contradictions of the state-led model of development - implemented in Brazil along most of the 20th century and 
intensified by the military governments making use of foreign savings through loans from multilateral banks - had resulted in growing economic inefficiencies and reliance on the continuous injection of capital by the state. Along the lines of the institutional changes introduced by the Real Plan, both generation and commercialisation of energy became then available to private national entrepreneurs, increasingly associated with international investors or energy companies. Because of the changing role of the state apparatus, increasingly focused on pro-private sector incentives, instead of direct construction and operation (which nonetheless continued to happen, despite the neoliberal discourse), very few hydropower schemes were built during the second period. Coordination and decision-making became significantly diffused across many agencies, without the presence of a centralised, well-equipped agency as during the military dictatorship. It represented a real tension between ambitious efficiency and operational goals and the reality of institutional fragmentation and diminished investments of the national government (GOLDENBERG; PRADO, 2003). The proclaimed virtues of the open energy market were never translated into investments and coordinated efforts. It culminated into the national energy crisis for nine months (June 2001 to March 2002), when energy offer was significantly reduced, caused by months with low rainfall, which required energy rationing at a very high political cost (leading to the loss of the 2002 presidential election by Cardoso's political group). According to a technical report of the National Energy Policy Council (2001), the failure to invest in new dams was responsible for $2 / 3$ of the energy rationing solution (KELMAN, 2001).

Considering the third politico-economic period, since 2003, the Amazon hydropower sector has provided an emblematic demonstration of the choreography of continuities and adjustments (BROGGIO et al., 2017). In the Madeira Basin, after a lengthy political dispute, the Jirau and Santo Antônio plants were licensed in July 2007, allowing the overflow of up to $529 \mathrm{~km}^{2}$. The two schemes have affected several indigenous groups, such as the Karitiana, Karipuna, UrueuWau-Wau, Katawixi and also other isolated, unnamed tribes (some living only 6 miles from the Jirau dam) who were forced to migrate to new lands where they clash with 'garimpeiros' (wildcat miners) logging companies while being exposed to diseases to which they had no immunity (LE CLÉZIO; RAZON, 2010). Another highly contentious project was Belo Monte, which has attracted great publicity in the international media (e.g. 29 articles posted by BBC News alone between 2010 and 2017). Belo Monte, still under construction, demonstrates that the neoliberalism platform was being cleverly adjusted to fulfil neo-developmental goals. It also epitomised the revival of the construction of large hydroelectric power plants in the Amazon and the encroachment of Brazilian energy demands upon neighbouring nations (because some schemes have flooded Bolivian land and Brazilian construction companies are deeply involved in projects in Peru, Venezuela and other countries). The project was partly inaugurated in 2016, with 11,233 MW of installed capacity and a 
cost of more than US\$ 13 billion. After its completion, Belo Monte is the fourth biggest hydropower in the planet, just behind Itaipu (inaugurated in 1984 on the border between Brazil and Paraguay) and Xiluodu and the Three Gorges Dam (in China).

The Belo Monte project, with another name (Cararaô), was originally conceived by the military in 1975 , but could not go ahead due to the collapse of the regime and its growing financial and political problems. The residents of Altamira (near the site of the dam) and the indigenous people keep up a resistance that is organised and quite influenced by the traumatic experience with Tucuruí. There was a large gathering in 1989 with more than 1,000 participants, including more than 600 indigenous people, which managed to attract international attention to the dispute and led to the cancellation of a World Bank loan under negation (CARVALHO, 2006). The neoliberal administration of President Cardoso revisited the proposal, but only really implemented by the government of Presidents Lula and Dilma. A consortium of state-owned companies (called Norte Energia [more details at http://norteenergiasa.com.br]) won the contract to build Belo Monte and manage it for 35 years. It is bewildering that the Lula government included many energy and environmental authorities who for a long time, fiercely opposed this and other similar projects in the past (e.g. PINGUELLI ROSA, 1989). The government had to respond to the criticism raised by environmental groups and local communities (including important Indian groups) who managed to form an international coalition against Belo Monte (that included Hollywood stars and famous artists). Capacity and transmission lines were reduced, and the new design removed the sizeable reservoir, in order to minimise the negative impacts. Moreover, the controversial features of Belo Monte continue to stir protest and serious resistance.

The project was the object of a lengthy battle in the courts, which led to repeated interruptions of the construction and operation (the last interruption ordered by a judge happened in 2017, but local groups also regularly occupy the site of the dam to protest against the unresolved problems associated with the project). The most controversial issue is related to the actual viability of the project without other supporting dams upstream. Due to the long dry season and the resulting long period of low flows in the Xingu River Basin (a common feature of eastern Amazon rivers), Belo Monte has low operation and economic performance if operating as a single dam. It means that a cascade of dams is necessary, but this would magnify the impacts on indigenous land, natural parks and farms. The national government has guaranteed, on many occasions that Belo Monte is the only large-scale dam of the Xingu River. However, the wider problem for Brazilian society is the low legitimacy and eroded trust in public authorities. This is a global phenomenon that seriously impacts on the quality of the formal democracy of many countries, Brazil included. Similar reassurances were given concerning the construction of other schemes in the Amazon, such as the 43 large dams to be implemented along the (even more vulnerable and controversial) Tapajós River 
by 2022 (FEARNSIDE, 2015). Those dams are directly benefiting from the friendly interpretation of the legislation and lax enforcement of water and environmental regulation, which means that several indigenous reserves and conservation areas will be flooded and degraded.

Abers et al. (2017) argue that the interests of the construction and business sectors for new infrastructure projects in the Amazon contrast with the persistent disregard for public participation and social demands, which reveals the contradictory and asymmetric priorities of the state. The granting of environmental and water licences in 2011, as much as public consultation required for the approval of the project, was notoriously undemocratic and strongly pushed forward by the federal government under the justification that economic growth needed additional sources of energy (SEVÁ FILHO, 2005). It is estimated that Belo Monte displaced between 20,000 and 50,000 people (including many families left behind after the collapse of rubber production in the early 1900s). At the same time, only 1/3 of the compensation promised by the authorities was ever paid (ANDERSON, 2017). For many activists and local communities, there is a distinctive feeling of betray and deception associated with Belo Monte (DIVERSI, 2014), especially because of the strange new alliances formed between left-wing politicians and conservative economic and political groups (MELO, 2016). The election of Lula, an important union leader, had raised great expectations, but once in office his government (2003-2010) was allied with the most archaic and corrupted politicians and construction companies in the country. It was no coincidence that the approval of Belo Monte involved systematic diversionary operations employed to divide the opposition and, at the same time, to legitimise the controversial project (ATKINS, 2017). During the Dilma government (2010-2016), which succeeded Lula's, the secret service was even asked to spy indigenous leaders, anthropologists and social movements who opposed the construction of Belo Monte (VALENTE; ARAGON, 2017).

Also disturbing were the dishonest practices employed for the construction of Belo Monte and many other oil and nuclear power plants, Olympic Games facilities, football stadiums and such like projects championed by Lula and his loyal successor Dilma (who was removed from office by the congress in 2016). Corruption and manipulation on an industrial scale were only property revealed through the work of the Lava-Jato [Carwash] Operation of the federal policy and the public prosecutor. Numerous politicians, operators and directors of engineering companies decided to collaborate with the judicial authorities, in order to secure a reduction of criminal penalties (plea bargain agreements). They exposed a monumental scheme involving bribing, illegal financing of electoral campaigns, flawed costing and engineering details, irregular granting of environmental and water licences, and cartelisation of the construction sector (CALIXTO, 2017). With the increasing arrest of top politicians, senior civil servants and owners of construction companies, and affecting a significant proportion of the congress, including the speakers of the Senate and the 
House, and several ministries (CASADO et al., 2017), it became clear that water and energy infrastructure in the Amazon are ingrained in the multiple operations conducted by the national state, in the name of development, but mainly favouring the interests established economic and political groups. A similar approach and involving the same construction companies (more notoriously, Odebrecht, South America's largest construction group) was responsible for the construction of hydropower projects in other countries, as in the case of the Lauca dam in Angola (LEAHY, 2016). Corruption is a CPE problem that feeds on local economic opportunities and connects these with national and transcontinental politics, as in the case of the scandals associated with hydropower construction.

In economic terms, Belo Monte stimulated a negotiation with Chinese investors to install an aluminium factory in the region of Barcarena (in the state of Pará) and the Canadian company Belo Sun to extract gold in the same area of the hydropower plant (the environmental licence granted in March 2017, but critics - such as Amazon Watch - say that the authorities ignored the risks; see POIRIER, 2017), among other similar projects. But there are further ramifications of the construction of new dams, which multiple the repercussions of corruption beyond the mere appropriation of public funds. The most relevant is the nexus between energy, mining, agribusiness and navigation. The justification of the new hydropower schemes seems to be increased both for energy generation for cities, industries and mining operations and also for the creation of new navigation routes. The new dams allow large-scale barges to pass rapids and cross waterfalls, which significantly reduces transport costs to ports along the Amazon River, accessible to transcontinental transportation ships, and ultimately increase the profitability and the areas of soybean cultivation (FEARNSIDE, 2015). At face value, it seems that there is a fantastic potential for the expansion of river navigation, considering that it only accounts for $4 \%$ of domestic Brazilian trade. However, it is almost certain that navigation plans will follow speculation and financialisation pressures, leading to land grabbing, chaotic migration and deforestation (BECKER, 2012). The growing politicoeconomic relevance of agribusiness in Brazil is directly connected with the challenges of water management and Amazon development (IORIS, 2020). The sector is commonly considered a great Brazilian achievement, due to technological improvements and production growth. However, the sector is also responsible for ecosystem degradation, contamination of water reserves, socio-spatial inequalities and macroeconomic vulnerability (IORIS, 2015). An apparent techno-economic success has encouraged further land and water grabbing, as the agribusiness sector has been unable to resolve long-lasting problems such as economic development that benefits small groups of largescale landowners, commercial companies and transnational corporations the expense of mounting environmental and social impacts. 


\section{CULTURAL REPERCUSSIONS AND THE SEARCH FOR JUSTICE: THE DIALECTICS OF DISTRIBUTION, RECOGNITION AND RESIGNIFICATION}

As discussed so far, what happened in the last four decades transformed the Amazon region into the main energy and agricultural frontier in Brazil, particularly because of the abundance of land and water and, notably, the limited ability of local groups to resist the strong advance of engineering infrastructure and plantation farms. One persistent feature of the process of socio-spatial change has been the overestimation of benefits and underestimation of impacts. Construction projects have created only a limited number of temporary jobs, but left a serious legacy of social disruption, violence, prostitution and many other pieces of evidence of human degradation (as in the recent case of the periphery of Altamira, massively transformed by the construction of Belo Monte). The benefits of those projects are grabbed in other parts of the country and abroad (in the form of energy and crop exports). At the same time, in the location of the dam, many suffer from water-borne diseases, unemployment, lowered income and sheer abandonment (regarding basic public services and human rights). The size of infrastructure may have changed, but there is a disturbing qualitative continuity between the colonial past, the developmental period and the neoliberalism present. The design and construction of hydropower schemes in the more recent development phase, centred on the production of primary commodities (minerals and agribusiness goods) for the global market replicates the disruptive and hierarchical practices earlier adopted in the name of colonisation, nation-building and, in the post-war decades, national development.

The politico-economic trends of regional development are complex, uneven, gendered and racialised, which have important differences and also commonalities with the experience in other parts of the world. On the one hand, the Amazon is unique because it contains the largest tropical rainforest in the world, still has many indigenous groups with distinctive cultural and linguistic traditions (increasingly being eroded) and has a unique history of colonisation and a marginal role in the various national economies. On the other hand, water development and dam building have been important elements of elite consolidation and hegemonic development plans, as described by Mohamud \& Verhoeven (2016) for the Nile Basin. There has been a comparable nexus between dams, political authority and ideological influences. As in the case of Chile, conflicts over proposed dams reveal the different meanings and values of nature, as much as contemporary water management approaches are permeated by market-based approaches that exacerbate uneven power relations (PALOMINO-SCHALSCHA et al., 2016). In China and Vietnam, just as in the Amazon, the local and disorganised populations endure the greatest impacts of water projects, whereas the positive results of hydropower schemes are primarily appropriated by energy companies and urban and industrialised parts of the country (ROUSSEAU et al., 2017). The Chinese mega-project of the 
Three Gorges Dam has also dispossessed local communities, contributed towards the formation of capital - in the form of contemporary primitive accumulation - and benefited from the help of politicians and bureaucrats, who have also reinforced their positions in the structures of power (WEBBER, 2012). The focus on the culture that underpins CPE can be considered a 'conjunctural approach' (LI, 2014) incorporating the socio-cultural, material and symbolic elements of a dynamic, contingent reality.

As in many other parts of the world, water management in the Amazon has been based on rent-seeking strategies at the expense of socio-ecological impacts and devastation of indigenous culture and local knowledge. The aggressive economic transformation of the Amazon has also resulted in novel lifestyles and consumer preferences that increasingly mirror the cultural patterns elsewhere in the main urban centres of Brazil (with the associated levels of consumerism, processed food, the spread of Evangelical churches, new music and dance styles born in the urban peripheries, etc.). The appeal of development and the imperative of economic growth at any cost has been embraced by both dictatorial right-wing governments and populist-nationalist presidents, whom all share the same ideological agenda. Moreover, as important as recognising the political and economic dimension of dam construction and the commonalities with other similar water development experiences is to comprehend how culture is seen as a realm which mediates all experience and can be mobilised for political action. Disputes and controversies around water are never simple or unidirectional, but reveal the ability of local actors - indigenous and nonindigenous groups in the case of the Amazon - to learn from past incidents and creatively react through a range of channels and with many different allies, just as communities affected by new dams have been reacting in the Upper Douro in Portugal (IORIS, 2012). The practical consequence is that the full analytical potential of CPE - considering subjectivities, historical agencies and cultural specificities of political and economic processes - is particularly relevant to both reject the biases of rigid structuralist approaches and the individualist excesses of post-structuralist authors mentioned above.

There at least three useful CPE lessons to be learned from reflecting on the Amazon experience. First, the emphasis on the symbolic and rhetoric components cannot diminish the materiality and physical aspects of culture. According to Peet \& Watts (2004), in the final decades of the last century, there was a post-modern obsession with reflexivity, which vainly emphasised words more than deeds, discourse rather than development, the hype over reality. There is even room here for a new epistemological 'turn' that properly emphasises materialist sensibilities and the transformative work of meaning-making cultural processes in the concreteness of the world (KIRSCH, 2012). Second, central to CPE is certainly the quest for justice, but this cannot be equated with the mainstream economist treatment of recognition as a mere epiphenomenon of 
distribution; in effect, the two - recognition and distribution - need to be articulated and theorised together (FRASER; HONNETH, 2003). The importance of recognition complements the typical emphasis of political economy on distribution, that is, CPE needs to redress the balance between the multiple and intricate dimensions of the lived and politicised reality. Recognition, including multiple struggles for identity and difference, is a central concept in a context of accelerated transcultural contacts as in the Amazon and should be articulated together with the claims of subaltern groups affected by regional development. It is significant that in that regard Sayer (2001) advocates a CPE based on a fuzzy distinction between the system (formal structures beyond the subjective experience of actors) and lifeworld (related to experience, informality and the culture in which actors socialise) that cuts across the culture-economy and recognition-distribution binaries.

The third main lesson, nonetheless, is that it is not sufficient to remove the artificially created binary between distribution and recognition. However, an accomplished CPE procedure requires extending the analytical framework with the additional politics of resignification. The argument informs the deployment of the concept of resignification here of Fraser (2009) that politico-economic pressures, as in the case of neoliberalism, can make concepts and collective reactions more ambiguous. The message is that discourses and symbols change and the historicity of complex dynamics needs to be carefully considered. However, resignification can also have the opposite effect, as long as it is included as a central element of the critique of current politicoeconomic pressures. Resignification - in the sense of a collective reimagination the public and private trends - can work as a mediator between the radical modification of economic processes and a serious and a politically meaningful appreciation of the cultural diversity of the Amazon. That echoes Williams (1977, p. 100) observation that mediation can be "seen as positive and substantial, as a necessary process of the making of meanings and values, in the necessary form of the general social process of signification and communication" that secures the reconciliation between opposing cognitive poles (in this case, the cultural and the economic).

The third term - resignification, in tandem with distribution and recognition - is increasingly needed to account for the interdependencies between the economic and more-thaneconomic impacts of the appropriation of rivers for hydropower dams. Moving beyond the micropolitics of post-structuralism - under the assumption that the specific and local experiences of minorities and marginalised groups hold the moral reservoir that macro-politics and large-scale changes lost - resignification represents, first of all, a commitment to reinterpreting and helping to overcome a perverse reality that is systematically reinforced and cuts across nested scales of interaction (from forest-dependent communities in remote catchments disrupted by hydropower schemes to national political coalitions and globalised markets). Resignification is directly connected with political semiotics, that is, the manifestation of power-relations in different semiotic 
systems in which identities are constructed and affect practices and relations. In that regard, a hegemonic interpretative order is predicated upon the exclusion of other symbolic possibilities; however, at the same time and depending on concrete politico-economic circumstances, counterhegemonic practices of resignification can emerge and challenge the status quo. Making use of the category of resignification, CPE can reveal a heuristic ability to particularly deal with the intricate politics of nature, rejecting 'economisms' and bringing together cultural questions, ecological challenges and grassroots politics (STEVENSON, 2015).

\section{CONCLUSIONS}

The three phases of dam construction in the Brazilian section of the Amazon since the 1960s have been marked by conflicting interests and socio-ecological impacts associated with the advance of national development plans. In order to make sense of the complexity and unevenness of modern water management, a CPE approach was employed to address the local specificities and wider political and economic 'conjuctures' that have facilitated the conversion of water into an economic resource. As in the case of canal construction for the Stalinist state, dams in the Amazon had the double aim to foster agro-industrial production and, also, to serve as an emblematic symbol of the modernisation of the Brazilian economy. Particularly the Belo Monte hydropower scheme, built along the Xingu River, reveals the persistence of authoritarianism, technocracy, unfairness and corruption behind narratives and projects that are supposed to boost national and democratic economic development.

One of the main conclusions to be drawn is that the sensibility to culture, agency and social identity must be connected with the wider macro-economic policies and national politics. In other words, the focus on culture and local circumstances cannot be invoked at the expanse of the equally important social, economic and political phenomena at the regional and national scale. There have been three critical moments of hydropower projects in the Amazon, evolving from a period of more direct state intervention to the more recent partnership with private construction companies. However, several important features have always remained present, such as the disregard from the existing socio-ecological features of the river basins involved and the attempt to convert shared waters into private sources of economic gain.

This leads to the second conclusion, which is exactly the need to address the politics of resignification, which is closely connected with the politics of redistribution and recognition. The advance of dams in the Amazon involved a systematic reduction of ecosystems, water and culture to means of production. Economic growth and regional development have largely depended on water, but first water has to be recreated as a hydropower resource divested of its other important features. 
The large-scale and speedy incorporation of water into economic development strategies only briefly mentioned above, demonstrates the persistent and systematic advance of modernity in the Amazon through the powerful resignification of water. Water lost most of its socio-cultural, ecological and geomorphological functions, mainly to fulfil exogenous demands for energy, navigation and agricultural expansion. It has been a phenomenon of epic proportions, involving both material and structural transformations of ecosystems, communities, lifestyles and socioeconomic arrangements (IORIS, 2017). At the centre of those processes of change lies the appropriation of territorial resources, such as water, and the conversion of the complexity and heterogeneity of the Amazon into the abstracted realm of market transactions and the circulation of capital. Essentially, it has been the tragedy of the non-commons and the widespread commonality of tragedy.

The third main conclusion is that traditional populations, affected by the reductionist pressures of regional development, were better equipped with understanding the vital importance of seasonal hydrology for their survival and social organisation. In that regard, the resignification and revaluation of their knowledge and techniques is an integral part of the critique of hegemonic water development. As inheritors of the knowledge accumulated by their ancestors, the populations dwelling along the banks of rivers possess a profound identity with the rivers, the soils, and the biodiversity of Amazonia. Through an intense interaction between society and nature, the traditional populations learned to respect the natural cycles and preserve the ecology of the rivers. Nevertheless, despite being populations that historically lived sustainably with regional nature, for the technocrats of development, these are largely marginalised sectors of society who can in an uncertain future have something to gain if the current mechanisms for exploiting Amazonia were increased even more. While not officially recognised, the misfortune of these populations facing the overwhelming process of economic growth will continue to be a symbolic test of the deep contradictions of modernity and development in the Amazon. In that sense, the examination of problems and the search for alternatives requires the proper resignification of ongoing economic trends and associated policies. Among many positive attributes, a focus on the politics of resignification can help to understand the impact of hegemonic pro-development ideologies and discourses, as well as comprehend the complexity of the interface between economic and morethan-economic practices. 


\section{REFERENCES}

ABERS, R. N.; OLIVEIRA, M. S.; PEREIRA, A. K. Inclusive Development and the Asymmetric State: Big Projects and Local Communities in the Brazilian Amazon. Journal of Development Studies, v. 53, n.6, p. 857-872, 2017.

ALTHUSSER, L. Philosophy of the Encounter: Later Writings 1978. New York: Verso, 2006. 220 p.

ANDERSON, M. Displaced by Brazil's Giant Belo Monte Hydroelectric Dam, 'River People' Reoccupy Reservoir, 2017. Available in: https://news.mongabay.com/2017/03/displaced-bybrazils-giant-belo-monte-hydroelectric-dam-river-people-reoccupy-reservoir. Access in: 30 dec. 2017.

ANEEL. Atlas de Energia Elétrica do Brasil. 3. ed. Brasília: Agência Nacional de Energia Elétrica, 2008. 243p.

ATKINS, E. Dammed and Diversionary: The Multi-dimensional Framing of Brazil's Belo Monte Dam. Singapore Journal of Tropical Geography, v. 38, n. 3, p. 276-292, 2017.

BECKER, B. K. Reflexões sobre Hidrelétricas na Amazônia: Água, Energia e Desenvolvimento. Boletim do Museu Paraense Emílio Goeldi (Ciências Humanas), v. 7, n. 3. p. 783-790, 2012.

BEST, J.; PATERSON, M. Cultural Political Economy. New York: Routledge, 2010. 264p.

BOND, P. South Africa's Next Revolt: Eco-Socialist Opportunities. In: PANITCH, L.; ALBO, G. Rethinking Revolution: Socialist Register 2017. London: Merlin Press, 2016. p. 161-185.

BOURDIEU, P. Science of Science and Reflexivity. Cambridge: Polity, 2004. 129p.

BROGGIO, C.; MARTINE, D.; PALLAMAR, J. P. Les Barrages Hydroélectriques Amazoniens, un Enjeu de Géopolitique Interne au Brésil. Hérodote, v. 165, n. 2, p. 185-203, 2017.

CALIXTO, B. O que as Delações da Odebrecht dizem sobre Corrupção nas Hidrelétricas da Amazônia. Revista Época, 2017. Avaialable in: http://epoca.globo.com/ciencia-e-meioambiente/blog-do-planeta/noticia/2017/04/o-que-delacoes-da-odebrecht-dizem-sobre-corrupcaonas-hidreletricas-da-amazonia.html. Access in: 14 apr. 2017.

CARVALHO, G. O. Environmental resistance and the politics of energy development in the Brazilian Amazon. Journal of Environment and Development, v. 15, n. 3, 245-268, 2006.

CASADO, L.; MATTOSO, C.; MEGALE, B. Ao TSE, delator cita Lobão e PMDB em Esquema de Propina de Belo Monte. Folha de São Paulo, 2017. Available in: http://www1.folha.uol.com.br/poder/2017/03/1869389-ao-tse-delator-cita-lobao-e-pmdb-emesquema-de-propina-de-belo-monte.shtml. Access in: 21 feb. 2017.

CHANG, H.-J. 23 Things They Don't Tell You about Capitalism. 1. ed. London: Penguin, 2011. $304 p$.

COMISSÃO PRÓ-ÍNDIO DE SÃO PAULO. 2nd Tribunal Internacional das Águas. Caso: As Hidrelétricas na Amazônia Brasileira. São Paulo: Comissão Pró-Índio de São Paulo, 1991. 296p. 
CONCA, K. Governing Water: Contentions Transnational Politics and Global Institution Building. Cambridge, Mass. \& London: MIT Press, 2006. 486p.

DIVERSI, M. Damming the Amazon: The Postcolonial March to the Wicked West. Cultural Studies - Critical Methodologies, v. 14, n. 3, p. 242-246, 2014.

FEARNSIDE, P. M. Amazon Dams and Waterways: Brazil's Tapajós Basin Plans. Ambio, v. 44, p. 426-439, 2015.

FEARNSIDE, P. M. Environmental and Social Impacts of Hydroelectric Dams in Brazilian Amazonia: Implications for the Aluminium Industry. World Development, v. 77, p. 48-65, 2016.

FIGES, O. The Whisperers: Private Life in Stalin's Russia. London: Penguin, 2008. 739p.

FRASER, N. Feminism, Capitalism and the Cunning of History. New Left Review, v. 56, p. 97$117,2009$.

FRASER, N.; HONNETH, A. Redistribution or Recognition? A Political-Philosophical Exchange. London and New York: Verso, 2003. 276p.

GOLDENBERG, J.; PRADO, L. T. S. Reforma e Crise do Setor Elétrico no Período FHC. Tempo Social - USP, v. 15, n. 2, p. 219-235, 2003.

GRAMSCI, A. Selections from the Prison Notebooks. London: Laurence and Wishart, 1971. $572 \mathrm{p}$.

GROSS, F. Désobéir. Paris: Flammarion, 2017. 144p.

HANNA, P.; VANCLAY, F.; LANGDON, E. J.; ARTS, J. The Importance of Cultural Aspects in Impact Assessment and Project Development: Reflections from a Case Study of a Hydroelectric Dam in Brazil. Impact Assessment and Project Appraisal, v. 34, n. 4, p. 306-318, 2016.

IORIS, A. A. R. The Troubled Waters of Brazil: Nature Commodification and Social Exclusion. Capitalism Nature Socialism, v. 18, n. 1, p. 28-50, 2007.

IORIS, A. A. R. Water Reforms in Brazil: Opportunities and Constraints. Journal of Environmental Planning and Management, v. 52, n. 6, p. 813-832, 2009.

IORIS, A. A. R. The Political Nexus between Water and Economics in Brazil: A Critique of Recent Policy Reforms. Review of Radical Political Economics, v. 42, n. 2, p. 231-250, 2010.

IORIS, A. A. R. The Political Geography of Environmental Regulation: Implementing the Water Framework Directive in the Douro River Basin, Portugal. Scottish Geographical Journal, v. 128, n. 1, p. 1-23, 2012.

IORIS, A. A. R. The Adaptive Nature of the Neoliberal State and the State-led Neoliberalisation of Nature: Unpacking the Political Economy of Water in Lima, Peru. New Political Economy, v. 18, n. 6, p. 912-938, 2013.

IORIS, A. A. R. The Production of Poverty and the Poverty of Production in the Amazon: Reflections from Those at the Sharp End of Development. Capitalism Nature Socialism, v. 26, n. 4, p. 176-192, 2015. 
IORIS, A. A. R. Rent of Agribusiness in the Amazon: A Case Study from Mato Grosso. Land Use Policy, v. 59, p. 456-466, 2016.

IORIS, A. A. R. Agribusiness and the Neoliberal Food System in Brazil: Frontiers and Fissures of Agro-neoliberalism. London: Routledge, 2017. 220p.

IORIS, A. A. R. Amazon's Dead Ends: Frontier-making the Centre. Political Geography, v. 65, p. 98-106, 2018.

IORIS, A. A. R. Peasant Farming in the Southern Tracts of the Amazon: The Reluctant Alterity of Agribusiness. Perspectives on Global Development and Technology, v. 18, p. 375-400, 2019.

IORIS, A. A. R. Frontier Making in the Amazon: Economic, Political and Socio-ecological Conversion. Switzerland: Springer, 2020. 222p.

JESSOP, B.; SUM, N.-L. Beyond the Regulation Approach: Putting Capitalist Economies in their Place. Cheltenham: Edward Elgar, 2006. 496p.

JESSOP, B.; OOSTERLYNCK, S. Cultural Political Economy: On Making the Cultural Turn without Falling into Soft Economic Sociology. Geoforum, v. 39, n. 3, p. 1155-1169, 2008.

KELMAN, J. Relatório da Comissão de Análise do Sistema Hidrotérmico de Energia Elétrica. Brasília: Conselho Nacional de Política Energética, 2001. 99p.

KIRSCH, S. Cultural Geography I: Materialist Turns. Progress in Human Geography, v. 37, n. 3, p. 433-441, 2012.

LATRUBESSE, E. M.; ARIMA, E. Y.; DUNNE, T.; PARK, E.; BAKER, V. R.; D'HORTA, F. M.; WIGHT, C.; WITTMANN, F.; ZUANON, J.; BAKER, P. A.; RIBAS, C. C.; NORGAARD, R. B.; FILIZOLA, N.; ANSAR, A.; FLYVBJERG, B.; STEVAUX, J. C. Damming the Rivers of the Amazon Basin. Nature, v. 546, p. 363-369, 2017.

LE CLEZIO, J-M. G.; RAZON, J.-P. Un Projet de GDF-Suez Met en Danger les Dernières Tribus Isolées d'Amazonie. Le Monde, 2010. Available in http://www.lemonde.fr/idees/article/2010/04/07/un-projet-de-gdf-suez-met-en-danger-les-dernierestribus-isolees-d-amazonie-par-jean-marie-g-le-clezio-et-jean-patrick-razon_1329918_3232.html. Access in: 04 jan. 2018.

LEAHY, J. A Brazilian Bribery Machine. Financial Times, 2016. Disponível em: https://www.ft.com/content/8edf5b2c-c868-11e6-9043-7e34c07b46ef. Acesso em: 28 dec. 2016.

LI, T. M. Land's End: Capitalist Relations on an Indigenous Frontier. Durham and London: Duke University Press, 2014. 240p.

MANN, G. Release the Hounds! The Marvelous Case of Political Economy. In: BARNES, T. J.; PECK, J.; SHEPPARD, E. The Wiley-Blackwell Companion to Economic Geography. Oxford: Blackwell, 2012. p. 61-73.

MARX, K. Capital. Vol. 1. Trans. B. Fowkes. London: Penguin, 1976. 574p.

MCCORMICK, S. Damming the Amazon: Local Movements and Transnational Struggles over Water. Society \& Natural Resources, v. 24, n. 1, p. 34-48, 2011. 
MELO, M. A. Crisis and integrity in Brazil. Journal of Democracy, v. 27, n. 2, p. 50-65, 2016.

MOHAMUD, M.; VERHOEVEN, H. Re-engineering the State, Awakening the Nation: Dams, Islamist Modernity and Nationalist Politics in Sudan. Water Alternatives, v. 9, n. 2, p. 182-202, 2016.

O'BRIEN, P. Debt and Sustainable Development in Latin America. In: GOODMAN, D.; REDCLIFT, M. Environment and Development in Latin America. Manchester and New York: Manchester University Press, 1991. p. 24-47.

PALOMINO-SCHALSCHA, M.; LEAMAN-CONSTANZO, C.; BOND, S. Contested Water, Contested Development: Unpacking the Hydro-social Cycle of the Nuble River, Chile. Third World Quarterly, v. 37, n. 5, p. 883-901, 2016.

PEET, R.; WATTS, M. Liberation Ecologies: Environment, Development, Social Movements. 2. ed. UK: Routledge, 2004. 444p.

PINGUELli ROSA, L. Hidrelétricas e Meio Ambiente na Amazônia. Análise Crítica do Plano 2010. Revista Brasileira de Energia, v. 1, n. 1, p. 7-24, 1989.

POIRIER, C. Toxic Mega-Mine Looms over Belo Monte's Affected Communities. 2017 Available in: http://amazonwatch.org/news/2017/0404-toxic-mega-mine-looms-over-belo-montesaffected-communities. Access in: 04 apr. 2017.

REIS, N.; MOLLINGA, P. P. Public Policy and the Idea of the Vietnamese State: The Cultural Political Economy of Domestic Water Supply. Asian Studies Review, v. 39, n. 4, p. 628-648, 2015.

ROUSSEAU, J. F.; ORANGE, D.; HABICH-SOBIEGALLA, S.; VAN THIET, N. Socialist Hydropower Governances Compared: Dams and Resettlement as Experienced by Dai and Thai societies from the Sino-Vietnamese Borderlands. Regional Environmental Change, v. 17, p. 2409-2419, 2017.

SAYER, A. Method in Social Science: A Realist Approach. 2. ed. London \& New York: Routledge, 1992. 328p.

SAYER, A. For a Critical Cultural Political Economy. Antipode, v. 33, p. 4, p. 687-708, 2001.

SCHOLZ, I. Environmental Policy Cooperation among Organised Civil Society, National Public Actors and International Actors in the Brazilian Amazon. European Journal of Development Research, v. 17, n. 4, p. 681-705, 2005.

SCOTT, J. C. Seeing Like a State. New Heaven and London: Yale University Press, 1998. 464p.

SEVÁ FILHO, A. O. Tenotã-Mõ: Alertas sobre as Consequências dos Projetos Hidrelétricos no Rio Xingu. São Paulo: International Rivers Network, 2005. 343p.

SIMONS, M. The Amazon Forest: Brazil Wants Its Dams, but At What Cost? The New York Times, 1989. Available in: http://www.nytimes.com/1989/03/12/weekinreview/the-world-theamazon-forest-brazil-wants-its-dams-but-at-what-cost.html. Access in: 25 mar. 2017.

STEVEnSON, N. Post-Citizenship, the New Left and the Democratic Commons. Citizenship Studies, v. 19, n. 6-7, p. 591-604, 2015. 
VALENTE, R.; ARAGON, R. Abin Espionou Indígenas e ONGs no Governo Dilma. Folha de São Paulo, 2017. Available in: http://www1.folha.uol.com.br/poder/2017/05/1882257-abin-espionouindigenas-e-ongs-no-governo-dilma.shtml. Access in: 09 may. 2017.

WEBBER, M. The Political Economy of the Three Gorges Project. Geographical Research, v. 50, n. 2, p. 154-165, 2012.

WILLIAMS, R. Marxism and Literature. Oxford University Press: Oxford and New York, 1977. $224 p$. 